\title{
Resistance of maize cultivars to Sitophilus zeamais (Coleoptera: Curculionidae)
}

\section{Resistência de cultivares de milho a Sitophillus zeamais (Coleoptera: Curculionidae)}

\author{
Carlos Aydano Virgínio Frazão ${ }^{1}$, Paulo Roberto Ramalho Silva', Welton Aaron de Almeida ${ }^{2}$, Emmanuel \\ Viana Pontual ${ }^{2}$, Glaucilane dos Santos $\mathrm{Cruz}^{2}$, Thiago Henrique Napoleãoº ${ }^{2}$ Solange Maria de França ${ }^{1 *}$
}

\begin{abstract}
Five Zea mays cultivars (BRS Caatingueiro, BRS Gorutuba, BRS Sertanejo, BRS Asa Branca and BR 106) were evaluated considering their effect on the nutrition of the maize weevil Sitophilus zeamais, by analysis of total protein in adult fed with these cultivars and for the presence of lectins and trypsin inhibitors in grains. In addition, free-choice and no-choice assays were performed to investigate the resistance of grains of the $Z$. mays cultivars to an attack by $S$. zeamais. The BR 106 cultivar showed the lowest susceptibility index, followed by BRS Caatingueiro, BRS Asa Branca, BRS Sertanejo and BRS Gorutuba. The number of emerged adults in the $Z$. mays cultivars ranged from 213.17 to 74.0, and the lowest number of insects was recorded for the BR 106 cultivar. The insects were able to feed on grains of all cultivars, but the BR 106 cultivar showed the least reduction in dried biomass. Lectins were detected in extracts from BR 106, BRS Asa Branca, BRS Sertanejo and BRS Gorutuba, and the highest activity was shown by BR 106. The lowest protein assimilation was detected in the insects from treatments with BRS Asa Branca. The extracts from all cultivars were able to inhibit the activity of bovine trypsin, but this effect was not related to the resistance degree of $Z$. mays cultivars. The results suggest the resistance of BR 160 to the attack of $S$. zeamais, as well as indicating that the presence of lectin in the grains is the cause of this resistance.
\end{abstract}

KEYWORDS: plant resistance; stored maize; lectins; trypsin inhibitors; maize weevil.
RESUMO: Foram avaliadas cinco cultivares de Zea mays (BRS Caatingueiro, BRS Gorutuba, BRS Sertanejo, BRS Asa Branca e BR 106) e seu efeito na nutrição do gorgulho-do-milho Sitophilus zeamais, por meio da análise de proteína total em adultos alimentados com esses cultivares e a presença de lectinas e inibidores da tripsina nos grãos. Além disso, foram realizados ensaios com e sem chance de escolha para investigar a resistência dos cultivares de $Z$. mays ao ataque de S. zeamais. O cultivar BR 106 apresentou o menor índice de susceptibilidade, seguido por BRS Caatingueiro, BRS Asa Branca, BRS Sertanejo e BRS Gorutuba. O número de adultos emergidos nos cultivares de $Z$. mays variou de 213,17 a 74,0 , e o menor número de insetos foi registrado para o cultivar BR 106. Os insetos foram capazes de se alimentar de todos os cultivares, no entanto, o BR 106 mostrou a menor redução na biomassa seca. As lectinas foram detectadas em extratos de BR 106, BRS Asa Branca, BRS Sertanejo e BRS Gorutuba, e a maior atividade foi demonstrada pela BR 106. A menor assimilaçáo de proteína foi detectada nos insetos que se alimentaram com BRS Asa Branca. Os extratos de todos os cultivares foram capazes de inibir a atividade da tripsina bovina, mas esse efeito não está correlacionado ao grau de resistência dos cultivares de $Z$. mays. Os resultados sugerem a resistência da BR 160 ao ataque de $S$. zeamais, além de indicar que a presença de lectina nos gráos é a causa dessa resistência.

PALAVRAS-CHAVE: resistência de plantas; milho armazenado; lectinas; inibidor de tripsina; gorgulho-do-milho.

'Universidade Federal do Piauí (UFPI) - Teresina (PI), Brazil

${ }^{2}$ Universidade Federal Rural de Pernambuco (UFRPE) - Recife (PE), Brazil

*Corresponding author: solangeufrpe@yahoo.com.br

Received on: 06/20/2017. Accepted on: 08/31/2018

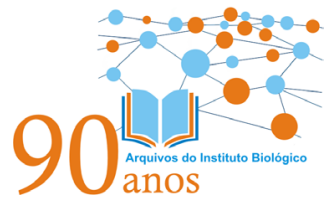




\section{INTRODUCTION}

Sitophilus zeamais Motschulsky, 1885 (Coleoptera, Curculionidae) is a major pest of maize in Brazil, and it may also occur on other important cereal crops, including rice, sorghum, and millet. However, its mean fecundity is highest on maize, causing economic losses, since it attacks stored grains, reducing their commercial value (SOUZA et al., 2012; OJO; OMOLOYE, 2016). The biological characteristics, including cross infestation and high biotic potential (FERRARI FILHO et al., 2011), have made it difficult to control this pest in warehouses. The use of synthetic insecticides represents the most widely used method for the control of stored grain pests. However, the indiscriminate and unplanned application of these chemicals has resulted in the selection of populations of resistant insects (LORINI, 2008; PEREIRA et al., 2009; CORRÊA et al., 2011). As an attempt to minimize this problem, the demand for environmentally friendly methods, including the use of cultivars resistant to pests, has grown (MARSARO JUNIOR et al., 2008; SIWALE et al., 2009; NASCIMENTO et al., 2014).

Resistance is one of the plant's various defence mechanisms against attacks by pests. Interest has thus been growing in studies that aim to detect proteins such as arcelin, lectin and protease inhibitors, which take part in these mechanisms. These studies help in the better selection of resistant cultivars (MARSARO JUNIOR et al., 2005; NAPOLEÃO et al., 2013). Proteins are essential for the survival, growth and fecundity of insects. Most insects use trypsin, a proteolytic enzyme, to break down proteins, and therefore tryp$\sin$ is found in the digestive tract of insects from different orders and of various feeding habits. Blocking trypsin activity can impair growth and development, or damage a number of physiological processes, killing insects by starvation. For this reason, trypsin inhibitors have gained attention as potential insecticidal agents (LAZAREVIC; JANKOVICTOMANIC, 2015).

Lectins are carbohydrate-binding proteins that can be found in different parts of plants such as seeds, seed husks, cladodes, flowers, leaves, rhizomes and roots (PAIVA et al., 2012). These proteins can be involved in plant defence against insects. Several studies have been conducted to determine the insecticidal mechanism of lectins, which can involve resistance to proteolysis in the insect midgut, interaction with glycoproteins from the peritrophic matrix, and interference in the activity of digestive enzymes (NAPOLEÃO et al., 2011; 2013).

This work investigated five Zea mays cultivars (BRS Caatingueiro, BRS Gorutuba, BRS Sertanejo, BRS Asa Branca and BR 106) and their effect on the nutrition of the maize weevil Sitophilus zeamais and for the presence of lectins and trypsin inhibitors. In addition, free-choice and no-choice assays were performed to investigate the resistance of grains of $Z$. mays cultivars to attacks by $S$. zeamais.

\section{MATERIALS AND METHODS}

\section{Plant material}

The $Z$. mays cultivars BRS Caatingueiro, BRS Gorutuba, BRS Sertanejo and BRS Asa Branca were provided by the Empresa Brasileira de Pesquisa Agropecuária (Embrapa), Petrolina, Pernambuco, Brazil, while the BR 106 cultivar was acquired from a private owner (Timon, Maranhão, Brazil), which is licensed by Embrapa Meio Norte.

\section{Insects}

S. zeamais adults originated from colonies maintained in the laboratory, obtained from breeding maintained, and provided by Embrapa Meio Norte. The insects were raised for several generations using popcorn-maize grains as substrate, and individuals were separated from week to week for homogenization of age. In order to eliminate infestation and promote moisture balance of grains, they were placed in plastic bags and stored in a freezer at $-10^{\circ} \mathrm{C}$ for seven days, eliminating any insect infestation from the field. After removal from the freezer, grains were transferred to glass flasks and kept in the laboratory at room temperature for 10 days, in order to reach hygroscopic equilibrium.

The experimental conditions during the study were: temperature of $28 \pm 2^{\circ} \mathrm{C}$, relative air humidity of $60 \pm 10 \%$ and 12-hour photoperiod.

\section{Survival and longevity of Sitophilus zeamais in no-choice assay}

Maize grains (200 g) of each cultivar were infested with 20 unsexed S. zeamais adults aged 10-20 days. The assay was performed in a plastic container (capacity of $500 \mathrm{~mL}$ ) closed with a perforated plastic lid, in order to facilitate gas exchange. Thirty days after the infestation, the number of emerged adults was recorded daily, and adults were removed from the plastic container. The assay was stopped after five consecutive days without emergence of adults, and the duration of the immature stage was determined as Equation 1 (LIMA et al., 2001):

$\Sigma \mathrm{x}$ number of days after infestation/total of emerged insects

$\Sigma=$ daily number of emerged insects.

The loss of grain mass due to the action of $S$. zeamais was determined according to MARSARO JUNIOR et al. (2006) with slight modifications, and recorded every 15 for 60 days after infestation of grains. The loss of grain mass was expressed as the difference between the dry weight of grains before infestation and the dry mass of grains at the end of the experiment. The resistance degree of the $Z$. mays 
cultivars was investigated through the susceptibility index (SI) (DOBIE, 1977), which lists the number of $S$. zeamais adults emerged and the average time of development after artificial infestation of grains. This index was determined by Equation 2:

$S I=\left[\left(\ln \left(\sum \mathrm{x}\right)\right) / \mathrm{T}\right]^{*} 100$

In which:

SI = susceptibility index;

$\ln =$ Naperian logarithm;

$\sum x=$ sum of the number of weevils that emerge from each hybrid;

$\mathrm{T}=$ mean time spent for the weevils to complete their biological cycle; a variable that was determined by the formula expressed on Equation 3:

$\mathrm{T}=\left(\sum \mathrm{xy} / \sum \mathrm{x}\right)$

In which:

$\mathrm{x}=$ number of weevils emerging daily;

$y=$ number of days from infestation to emergence.

The experimental design was completely randomized, and the data were expressed as means of five replicates \pm standard deviations, and submitted to variance analysis followed by Tukey's post-test at 5\% probability, using Statistical Analysis System (SAS) (SAS INSTITUTE, 2001).

\section{Free-choice assay}

The assays were performed in experimental arenas that consisted of five plastic containers ( $150 \mathrm{~mL}$ of capacity) connected by plastic tubes $(9 \mathrm{~cm})$ to a central plastic box. Each container received one of five cultivars $(10 \mathrm{~g})$, while in the central arena 50 unsexed S. zeamais adults, $0-20$ days old, were released. After 24 hours, the interlinkages between the compartments were closed with cotton, and the number of insects in each container was recorded. The experimental design was completely randomized, and six replicates were performed. The number of attracted insects was used to make the analysis of frequency of choice, and the data were submitted by $\chi^{2}$ test at $5 \%$ probability using PROC FREQ (SAS INSTITUTE, 2001).

\section{Analysis of total protein from S. zeamais}

Unsexed S. zeamais adults were separated into five groups, each fed grain with one of five $Z$. mays cultivars (BR 106, BRS Caatingueiro, BRS Gorutuba, BRS Sertanejo and BRS Asa Branca) for one biological cycle and separated for the analysis of total protein. The insects were placed in flat-bottomed glass tubes. After that, the insects were immobilized at $4^{\circ} \mathrm{C}$, and macerated in sodium phosphate buffer $(\mathrm{pH}=7.4$,
$0.1 \mathrm{M}$ ) in the ratio of four adults $/ 5 \mathrm{~mL}$ of buffer. The mixture $(1 \mathrm{~mL})$ was stored in a properly labelled microtubule. The procedure was carried out at low temperature to prevent the sample from oxidizing. After centrifugation (3 min, $3,000 \mathrm{rpm}), 100 \mu \mathrm{L}$ of each sample was taken, and $5 \mathrm{~mL}$ of the Bradford reagent $(0.01 \%$ coomassie blue G- $250,8.5 \%$ phosphoric acid and $4.7 \%$ ethanol) was added. The samples were agitated in a vortex and then stood at rest for $2 \mathrm{~min}$ (time to interact with the reagent). The absorbance was read for each sample in a spectrophotometer in a wavelength of $595 \mathrm{~nm}$ expressed as $\mu \mathrm{g} / \mathrm{mL}$. The results were submitted to ANOVA and means compared by Tukey test at $5 \%$ probability using SAS Proc GLM (SAS INSTITUTE, 2001).

\section{Investigation of Zea mays cultivars for the presence of lectins and protease inhibitors}

The grains $(10 \mathrm{~g})$ of the five $Z$. mays cultivars were powdered, and five extracts were obtained after homogenization with $0.15 \mathrm{M}$ $\mathrm{NaCl}(50 \mathrm{~mL})$. Each extract was investigated for the presence of lectins (hemagglutinating activity) and trypsin inhibitors.

Hemagglutinating activity was investigated according to NAPOLEÃO et al. (2011) by mixing a twofold serial dilution of each $Z$. mays extract $(50 \mu \mathrm{L})$ in $0.15 \mathrm{M} \mathrm{NaCl}$ in microtiter plates (Techno Plastic Products-TPP, Trasadingen, Switzerland). Next, $50 \mu \mathrm{L}$ of a suspension $(2.5 \% \mathrm{v} / \mathrm{v})$ of glutaraldehyde-treated rabbit erythrocytes (BING et al., 1967) in $0.15 \mathrm{M} \mathrm{NaCl}$ was added to each well, and the plate was incubated at $27^{\circ} \mathrm{C}$ for 45 minutes. One hemagglutination unit was defined as the reciprocal value of the highest dilution of sample that promoted full agglutination of erythrocytes. The susceptibility index, adult emergence, the larval phase duration, the loss of weight of cultivars and the total amount of proteins in the insect correlated with lectin levels and presence of trypsin inhibitors. The data were submitted to regression analysis, and those equations that best represented the biological response were selected, based on their significance $(\mathrm{F}$ and $\mathrm{P})$ and higher coefficient of determination (R2). All tests were conducted using the statistical program SAS version 8.02 (SAS INSTITUTE, 2001).

The presence of trypsin inhibitors in $Z$. mays extracts was evaluated according to PONTUAL et al. (2014). Bovine tryp$\sin (5 \mu \mathrm{L} ; 0.1 \mathrm{mg} / \mathrm{mL}$ in $0.1 \mathrm{M}$ Tris- $\mathrm{HCl} \mathrm{pH} 8.0$ containing $0.02 \mathrm{M} \mathrm{CaCl}_{2}$ ) was incubated for $5 \mathrm{~min}$ at $37^{\circ} \mathrm{C}$ with the extracts $(5-15 \mu \mathrm{L})$ in one well of a 96-well microplate. The assay volume was adjusted to $195 \mu \mathrm{L}$ with Tris- $\mathrm{HCl} \mathrm{pH}$ 8.0. Next, the substrate N-benzoyl-DL-arginyl-q-nitroanilide $(8 \mathrm{mM})$ dissolved in dimethyl sulfoxide (DMSO) was added $(5 \mu \mathrm{L})$, and the mixture was incubated for $30 \mathrm{~min}$ at $37^{\circ} \mathrm{C}$. As a control (100\% substrate hydrolysis), the reaction was performed by replacing $Z$. mays extracts with distilled 
water $(20 \mu \mathrm{L})$. The hydrolysis of substrate was determined by measuring the absorbance at $405 \mathrm{~nm}$ with a microplate spectrophotometer (iQuant, MQX200; BioTek Instruments, Inc., Vermont, United States). Blanks were performed under the same conditions, in absence of the substrate or the enzyme. One unit of trypsin inhibitor activity corresponded to the amount of trypsin inhibitor that decreased the absorbance by 0.01 after $30 \mathrm{~min}$ at $37^{\circ} \mathrm{C}$, regarding the control. Specific trypsin inhibitor activity $(\mathrm{U} \mathrm{mg} / \mathrm{mL})$ corresponded to the ratio between the inhibitor activity $(\mathrm{U})$ and protein concentration (mg).

\section{RESULTS}

The no-choice assay revealed that the ingestion of the five $Z$. mays cultivars did not interfere in the development of S. zeamais, since the duration of the immature phase (days) was similar in all treatments. On the other hand, a lower number of adults emerged from the treatment with cultivar BR 106 , although the number was statistically similar to those with BRS Sertanejo and BRS Gorutuba, and different only from BRS Caatingueiro. The number of emerged adults and the susceptibility index were higher for BRS Caatingueiro and BRS Asa Branca. Cultivar BRS Caatingueiro showed the highest susceptibility index (9.80), but did not differ significantly from cultivars BRS Sertanejo and BRS Gorutuba, while BR 106 showed the lowest susceptibility index (7.66) than the other cultivars tested under $S$. zemais attack (Table 1).

On the $15^{\text {th }}$ day of confinement after infestation, the presence of the insects did not cause significant loss in the mass of dry grains. It was only after 30 days of confinement that significant losses of dry mass could be observed in the maize cultivars tested. Cultivar BR 106 was the most resistant, since it presented the lowest loss of dry mass $(3.27 \mathrm{~g})$ at 60 days after infestation of the grains by $S$. zeamais adults, while the other varieties lost between $9.28 \mathrm{~g}$ (BRS Asa Branca) and $7.36 \mathrm{~g}$ (BRS Gorutuba) (Fig. 1).

The results from the free-choice assay revealed that the number of insects present in maize cultivars BRS Gorutuba and BRS Sertanejo was significantly lower than those found in BRS Caatingueiro and BRS Asa Branca. The last of them is therefore the most attractive option under the experimental conditions, while BR 106 is intermediate between the most and least attractive (Fig. 2).

The protein content of $S$. zeamais fed with BRS Caatingueiro $(33.08 \pm 1.89 \mu \mathrm{g} / \mathrm{mL})$, BRS Sertanejo $(29.75 \pm 1.64 \mu \mathrm{g} / \mathrm{mL})$ and BRS Gorutuba $(28.50 \pm 2.10 \mu \mathrm{g} / \mathrm{mL})$ was not significantly different, indicating that these cultivars did not interfere in the acquirement of proteins by $S$. zeamais adults. However, the lowest protein assimilation was detected in the insects from treatments with BRS Asa Branca $(18.35 \pm 1.27 \mu \mathrm{g} / \mathrm{mL})$.

The results from the investigation of $Z$. mays cultivars for the presence of lectins and protease inhibitors showed that extracts from BR 106, BRS Asa Branca, BRS Sertanejo and BRS Gorutuba were able to agglutinate rabbit erythrocytes with titers of 4.86, 2.59, 1.84 and $1.29 \mathrm{U} / \mathrm{mg}$, respectively (Fig. 3). It indicates the presence of lectins in these extracts. However, the extract from BRS Caatingueiro did not show hemagglutinating activity, and, therefore, we assumed that this extract did not contain lectins.

Statistical analysis showed significant correlations between the dry mass loss $(\mathrm{F}=11.84 ; \mathrm{p}=0.0018)$; the adult emergence $\left(\mathrm{F}=15.84 ; \mathrm{p}<0.0004, \mathrm{R}^{2}=0.40\right)$; the susceptibility index $(\mathrm{F}=8.29 ; \mathrm{p}=0.0075)$, and the total protein content

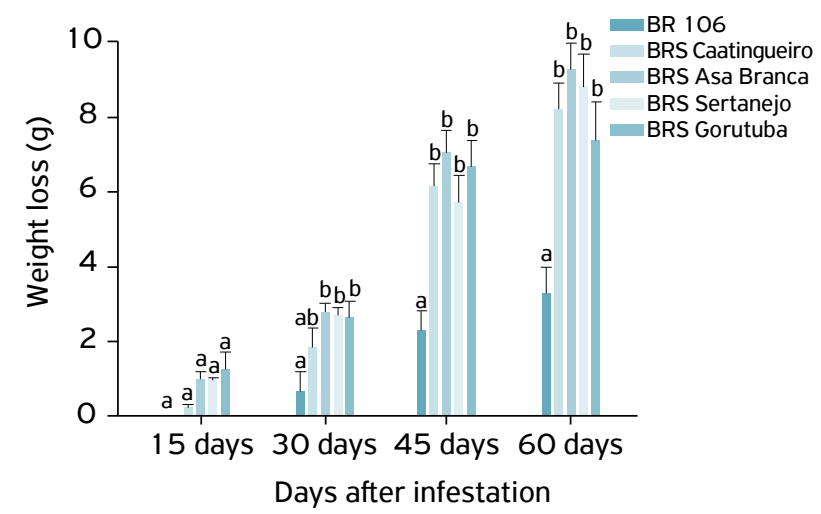

Note: Bars followed by the same letter, in the same time interval, do not differ significantly by Tukey test ( $\mathrm{p} \leq 0.05$ ).

Figure 1. Weight loss of different maize cultivars submitted to Sitophilus zeamais attack.

Table 1. Number (mean \pm SE) of Sitophilus zeamais emerged, duration of the immature phase, susceptibility index and proteins in S. zeamais obtained after feeding on maize cultivars in no-choice test.

\begin{tabular}{|c|c|c|c|c|}
\hline Cultivars of maize & $\begin{array}{c}\text { Duration of the } \\
\text { immature phase (day) }\end{array}$ & $\begin{array}{c}\text { Number of } \\
\text { adults emerged }{ }^{1}\end{array}$ & Susceptibility index ${ }^{1}$ & $\begin{array}{c}\text { Proteins in } \\
\text { S. zeamais }(\mu \mathrm{g} / \mathrm{mL})^{1}\end{array}$ \\
\hline BRS Caatingueiro & $54.65 \pm 1.09 a$ & $213.17 \pm 17.38 a$ & $9.80 \pm 0.27 a$ & $33.08 \pm 1.89 a$ \\
\hline BRS Asa Branca & $55.31 \pm 1.74 a$ & $174.83 \pm 23.54 a b$ & $9.34 \pm 0.54 a b$ & $18.35 \pm 1.27 c$ \\
\hline BRS Sertanejo & $55.52 \pm 0.51 a$ & $136.50 \pm 17.22 b c$ & $8.79 \pm 8.79 b c$ & $29.75 \pm 1.64 \mathrm{ba}$ \\
\hline BRS Gorutuba & $58.79 \pm 1.19 a$ & $130.50 \pm 24.93 b c$ & $8.17 \pm 0.43 b c$ & $28.50 \pm 2.10 \mathrm{ba}$ \\
\hline BR 106 & $55.54 \pm 1.54 a$ & $74.00 \pm 11,92 c$ & $7.66 \pm 0.34 c$ & $23.03 \pm 1.66 \mathrm{bc}$ \\
\hline
\end{tabular}

'Means followed by the same letter do not differ statistically by Tukey test $(p \leq 0.05)$; SE: standard error. 
of $S$. zemais $(\mathrm{F}=14.61 ; \mathrm{p}<0.0007)$ and the lectin activity. On the other hand, no statistical correlation $(\mathrm{F}=0.03 ; \mathrm{p}<0.85)$ was detected between the biological cycle of $S$. zemais and the presence of lectins (Table 2).

BRS Sertanejo, BRS Asa Branca, BR 106, BRS Gorutuba and BRS Caatingueiro were able to inhibit the hydrolytic activity of commercial trypsin (Fig. 3). However, there was no significant correlation between the dry mass loss ( $\mathrm{F}=1.49$; $\mathrm{p}=0.23)$; the adult emergence $(\mathrm{F}=0.84 ; \mathrm{p}<1.36)$; the susceptibility index $(\mathrm{F}=0.16 ; \mathrm{P}=0.69)$, and the total protein content of $S$. zemais $(\mathrm{F}=0.17 ; \mathrm{p}<0.68)$ and trypsin activity.

\section{DISCUSSION}

Plants resistant to the attack of herbivores express a set of compounds that makes their tissues indigestible by the predators. Therefore, ingesting these plants results in high energy consumption and can affect the life cycle, development and efficiency in the conversion of ingested food into biomass by insects (CORREIA; SALGADO, 2011). For this reason, this work focused on the effects of the ingestion of different $Z$. mays cultivars on dry mass loss, number of emerged adults, and the total protein content from $S$. zemais.

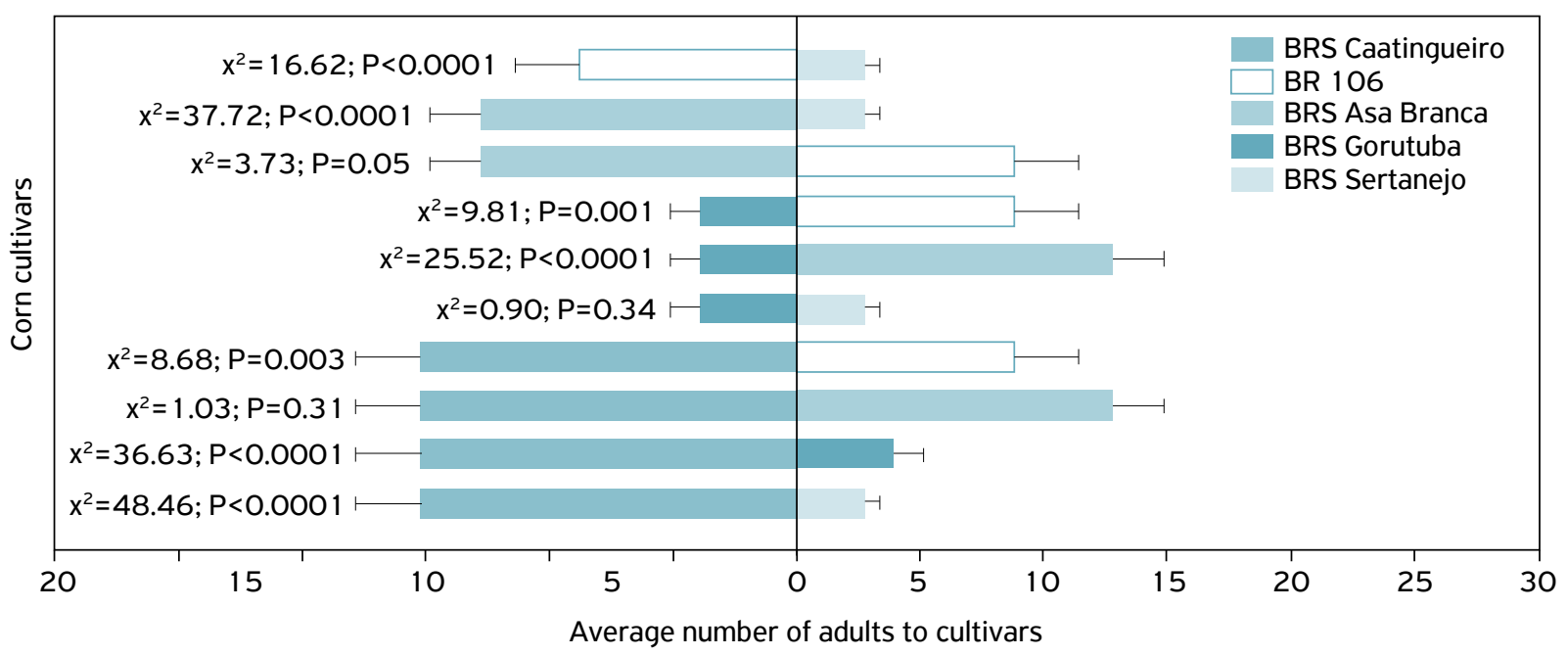

Figure 2. Preference of the adult Sitophilus zeamais $(n=435)$ of commercial cultivars of maize seeds. Statistically significant by $c^{2}$ test.

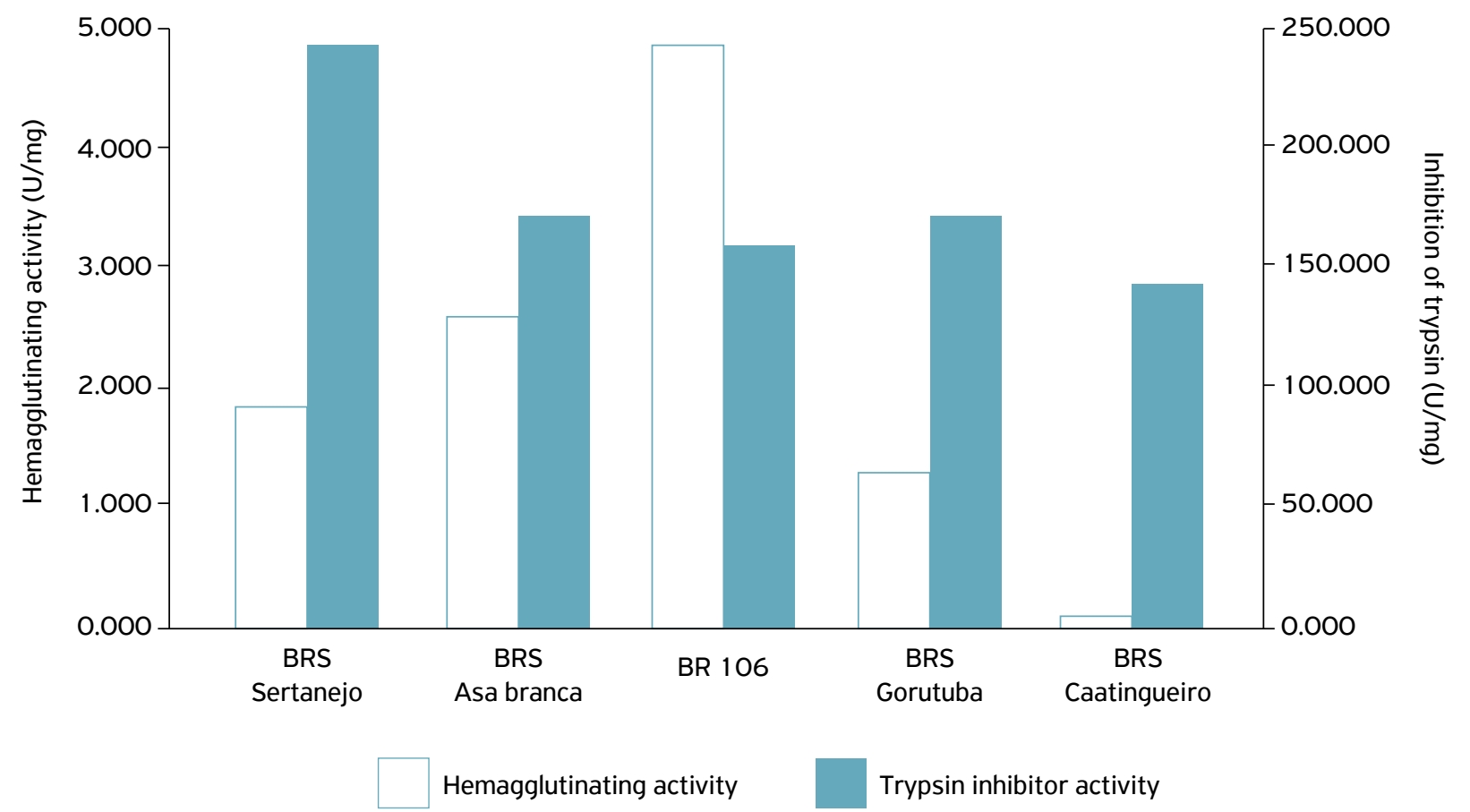

Figure 3. Hemagglutination activities and inhibition of trypsin in different maize varieties. 
Table 2. Equations for loss of weight of cultivars, adult emergence, susceptibility index, biological cycle and total amount of total protein in Sitophilus zemais fed cultivars with different levels of lectins and their assessed parameters ( $F$, Test Fisher, $p$, of the significance and value, $\mathrm{R}^{2}$, coefficient of determination).

\begin{tabular}{lccccc} 
Treatment & Parameters assessed & Equations & \multicolumn{1}{c}{$\mathbf{F}^{\mathbf{P}}$} & $\mathbf{R}^{2}$ \\
\hline Lectins & Loss of weight of cultivars & $\hat{y}=9.42-0.96 x$ & $11.84^{<0.0018}$ & 0.35 \\
\hline Adult emergence & $\hat{y}=196.31-23.86 x$ & $15.84^{<0,0004}$ & 0.40 \\
\hline Biological cycle & $\hat{y}=50.10-0.06 x$ & $0.03^{<0.85}$ & 0.02 \\
\hline Susceptibility index & $\hat{y}=9.48-0.34 x$ & $8.29^{<0.0075}$ & 0.35 \\
\hline Total protein in S. zemais & $\hat{y}=31.52-0.34 x$ & $14.61^{<0.0007}$ & 0.35 \\
\hline
\end{tabular}

Similar to the results obtained in the no-choice assay using cultivar BR 106, MARSARO JUNIOR et al. (2008) detected reduction in the emergence of adult insects when working with maize cultivars resistant to the attack of $S$. zeamais.

NUNES; RIZENTAL (2015) also exposed S. zeamais to resistant maize varieties and demonstrated that the ingestion of these grains reduced the survival of the insects. These results corroborate those found in this study, in which the most resistant cultivar, BR 106, followed by BRS Sertanejo and BRS Gorutuba, promoted reduction in adult emergence. Since antibiosis is a disharmonious relationship in which a population of individuals secrete substances that inhibit or prevent the development of populations of individuals of other species, it seems to be the kind of relationship between the cultivars tested here and $S$. zeamais.

A plant expressing antibiosis may affect the reproductive potential of insects due to the mortality at the immature stage, the low emergence of adults, and the reduction in size and weight of individuals. This mechanism can also change the longevity, oviposition, mortality, and fecundity of insects, promoting the cycle's elongation (MIKAMI et al., 2012). In addition, the sub-lethal effect on the biology of insect pests includes populations with less vigorous individuals and that are more susceptible to insecticide action over the generations (FARINELLI; FORNASIERI FILHO, 2006).

Another feature of cultivars resistant to insect pests is the reduction in the loss of dry mass of the grains after being infested (MARSARO JUNIOR et al., 2005), as observed for cultivar BR 106, which showed itself to be the cultivar most resistant to $S$. zeamais attack in this investigation. This inability of $S$. zeamais to settle in BR 106 grains may characterize a case of antixenosis; in other words, a non-preference for oviposition or feeding. The test with free choice revealed that BRS Gorutuba and BRS Sertanejo were less attractive to S. zeamais, when considering the number of insects attracted to the cultivars, while BR 106 stood in an intermediate position between the most and least attractive.

Antixenosis (or non-preference) refers to how much damage is suffered or how many herbivore individuals a plant attracts during a specific time. Antixenosis can be plant focused or can be seen from the herbivores' perspective. When focused on herbivore presence, its measurement is carried out by means of the number of eggs, larvae, or adults in a pre-set time (STENBERG; MUOLA, 2017). It should also be noted that the plant does not represent to the insect only a food source, but also a place of reproduction and shelter, so several characteristics can make a plant preferential or not for a certain insect (THOMPSON; PELLMYR, 1991).

Plant lectins interfere with the feeding, development, reproduction and survival of insects at different stages and, for this reason, are related to the plant's resistance to insects (SÁ et al., 2009). Thus, in the present work the presence of lectins in the $Z$. mays cultivars was investigated. Interestingly, BRS Caatingueiro was the most susceptible to $S$. zeamais in comparison with the other cultivars, and lectin activity was not detected in this cultivar. On the other hand, the cultivars with the highest lectin activity (BR 106 and BRS Gorutuba) showed lower emergence of $S$. zeamais adults and presented smaller loss of dry mass.

Although MIKAMI et al. (2012) state that protein levels do not affect the resistance of $Z$. mays to $S$. zeamais, our results demonstrated that higher concentrations of lectins were statistically correlated with resistance. It was previously reported that the lectin from leaves of Myracrodruon urundeuva (Sapindales: Anacardiaceae) was able to cause imbalance in the digestive enzymes of S. zeamais (NAPOLEÃO et al., 2013). Therefore, it can be affirmed that cultivar BR 106 showed higher resistance to S. zeamais attack; that the presence of lectins and trypsin inhibitors influenced the resistance of cultivars BR 106, BRS Caatingueiro, BRS Asa Branca, BRS Sertanejo and BRS Gorutuba to the attack of S. zeamais; and that the high inhibitory activity of trypsin prolonged the biological cycle of the weevil and, consequently, increased the resistance of the cultivars, as well as having probably influenced the dry matter intake of maize grain.

\section{ACKNOWLEDGMENTS}

We thank the Coordenação de Aperfeiçoamento de Pessoal de Nível Superior (CAPES), from Brazil, Finance Code 001. 

REFERENCES

BING, D.H.; WEYAND, J.G.M.; STAVISTSKY, A.B. Hemagglutination with aldehydefixed erythrocytes for assay of antigens and antibodies. Proceedings of the Society for Experimental Biology and Medicine, New York, v.124, n.4, p. $1166-1170,1967$

CORREAA, A.S.; PEREIRA, E.J.G.; CORDEIRO, E.M.G.; BRAGA, L.S.; GUEDES, R.N.C. Insecticide resistance, mixture potentiation and fitness in populations of the maize weevil (Sitophilus zeamais). Crop Protection, v.30, n.12, p.1655-1666, 2011.

CORREIA, J.C.R.; SALGADO, H.R.N. Atividade inseticida de plantas e suas aplicações. Revista Brasileira de Plantas Medicinais, Botucatu, v.13, n.4, p.500-506, 2011.

DOBIE, P. The contribution of the tropical stored products centre to the study of insect resistance in stored maize. Tropical Stored Product, Tokyo, v.34, p.7-22, 1977.

FARINELLI, R.; FORNASIERI FILHO, D. Avaliação de dano de Spodoptera frugiperda (J. E. Smith, 1797) (Lepidoptera: Noctuidae) em cultivares de milho. Revista Científica, v.34, n.2, p.197-202, 2006. http://dx.doi. org/10.15361/1984-5529.2006v34n2p 197+-+202

FERRARI FILHO, E.; ANTUNES, L.E.G.; TIECKER, A.; DIONELLO, R.G.; SPOLTI, P. Controle de Gorgulho-do-milho Submetido ao tratamento térmico. Revista Brasileira de Milho e Sorgo, Sete Lagoas, v.10, p.196-204, 2011.

LAZAREVIC, J.; JANKOVIC-TOMANIC, M. Dietary and phylogenetic correlates of digestive trypsin activity in insect pests. Entomologia Experimentalis et Applicata, Netherlands, v.157, n.2, p.123-151, 2015.

LIMA, M.P.L.; OLIVEIRA, J.V.; BARROS, R.; TORRES, J.B Identificação de Genótipos de Caupi Vigna unguiculata (L.) Walp. Resistentes a Callosobruchus maculatus (Fabr.) (Coleoptera: Bruchidae). Neotropical Entomology, Londrina, v.30, n.2, p.289-295, 2001.

LORINI, I. Manejo integrado de pragas de grãos de cereais armazenados. Passo Fundo: Embrapa Trigo, 2008. 72p.

MARSARO JÚNIOR, A.L.; LAZARRI, S.M.N.; FIGUEIRA, E.L.Z.; HIROOKA, E.Y. Inibidores de amilase em híbridos de milho como fator de resistência a Sitophilus zeamais (Coleoptera: Curculionidae). Neotropical Entomology, Londrina, v.34, n.3, p.443-450, 2005.

MARSARO JÚNIOR, A.L.; LAZARRI, S.M.N.; PINTO JÚNIOR, A.R. Inibidores de enzimas digestivas de insetos-praga. Revisto Acadêmica de Curitiba, Curitiba, v.4, p.57-61, 2006.

MARSARO JÚNIOR, A.L.; VILARINHO, A.A.; PAIVA, W.R.S.C.; BARRETO, H.C.S. Resistência de híbridos de milho ao ataque de Sitophilus zeamais Motschulsky (Coleoptera: Curculionidae) em condições de armazenamento. Revista Acadêmica, Ciências Agrárias e Ambientais, Curitiba, v.6, n.45-50, 2008.
MIKAMI, A.Y.; CARPENTIERI-PÍPOLO, V.; VENTURA, M.U. Resistance of Maize Landraces to the Maize Weevil Sitophilus zeamais Motsch. (Coleoptera: Curculionidae). Neotropical Entomology, Londrina, v.41, n.5, p.404-408, 2012.

NAPOLEÃO, T.H.; GOMES, F.S.; LIMA, T.A.; SANTOS, N.D.L.; SÁ, R.A.; ALBURQUERQUE, A.C.; COELHO, L.C.B.B.; PAIVA, P.M.G. Termiticidal activity of lectins from Myracrodruon urundeuva against Nasutitermes corniger and its mechanisms. International Biodeterioration \& Biodegradation, Manchester, v.65, n.1., p.52-59, 2011.

NAPOLEÃO, T.H.; BELMONTE, B.R.; PONTUAL, E.V.; ALBUQUERQUE, L.P.; SÁ, R.A.; PAIVA, L.M.; COELHO, L.C.B.B.; PAIVA, P.M.G. Deleterious effects of Myracrodruon urundeuva leaf extract and lectin on the maize weevil, Sitophilus zeamais (Coleoptera, Curculionidae). Journal of Stored Products Research, v.54, p.26-33, 2013

NASCIMENTO, R.J.; PAVAN, B.E.; SILVA, L.B.; CARVALHO, G.S.; SILVA, A.F.; MAGGION, K. Resistance of Two Maize Landraces in Breeding Stage to the Attack of Sitophilus zeamais. American Journal of Plant Sciences, v.5, p.2929-2934, 2014.

NUNES, M.P.; RIZENTAL, M. Preferência alimentar de Sitophilus zeamais (Coleoptera: Curculionidae) em variedades de milho transgênico. Conectionline, Várzea Grande, n.12, p.84-89, 2015.

OJO, J.A.; OMOLOYE, A.A. Development and Life History of Sitophilus zeamais (Coleoptera: Curculionidae) on Cereal Crops. Advances in Agriculture, p. 1-8, 2016.

PAIVA, P.M.G.; NAPOLEÃO, T.H.; SÁ, R.A.; COELHO, L.C.B.B. Insecticide activity of lectins and secondary metabolites. In: PERVEEN, F. (Eds) Insecticides - advances in integrated pest management. Croatia: Intech, 2012. p.579-598.

PEREIRA, C.J.; PEREIRA, E.J.C.; CORDEIRO, E.M.G.; DELLA LUCIA, T.M.C.; TÓTOLA, M.R.; GUEDES, R.N.C. Organophosphate resistance in the maize weevil Sitophilus zeamais: Magnitude and behavior. Crop Protection, v.28, p.168-173, 2009.

SÁ, R.A.; SANTOS, N.D.; SILVA, C.S.; NAPOLEÃO, N.T.; GOMES, F.S.; CAVADA, B.S.; COELHO, L.C.; NAVARRO, D.M.A.F.; BIEBER, L.W.; PAIVA, P.M. Larvicidal activity of lectins from Myracrodruon urundeuva on Aedes aegypti. Comparative Biochemistry and Physiology, Part C, v.149, n.3, p.300-306, 2009.

PONTUAL, E.V.; SANTOS, N.D.L.; MOURA, M.C.; COELHO, L.C.B.B.; NAVARRO, D.M.A.F.; NAPOLEÃO, T.H.; PAIVA, P.M.G. Trypsin inhibitor from Moringa oleifera flowers interferes with survival and development of Aedes aegypti larvae and kills bacteria inhabitant of larvae midgut. Parasitology Research, v.113, n.2, p.727-733, 2014.

SIWALE, J.; MBATA, K.; MCROBERT, J.; LUNGU, D. Comparative resistance of improved maize genotypes and landraces to maize weevil. African Crop Science Journal, Uganda, v.17, n. 1, p. 1-16, 2009. 
SAS INSTITUTE Inc. System for Microsoft Windows, Release 8.2, Cary, NC, USA. 1999-2001.

SOUZA, A.R.; SILVA, T.M.; SANTOS, J.F.L. Seleção e desenvolvimento de Sitophilus oryzae (Linné, 1763) em três substratos. Magistra, Bahia, v.24, p.160-163, 2012.
STENBERG, J.A.; MUOLA, A. How should plant resistance to herbivores be measured? Frontiers in Plant Science, v.8, article 163, 2017.

THOMPSON, J.N.; PELLMYR, O. Evolution of oviposition behavior and host preference in Lepidoptera. Annual Review of Entomology, Washington, v.36, p.65-89, 1991. 